\title{
Perlindungan Masyarakat Hukum Adat dalam Konstitusi sebagai Perwujudan Asas Equality Before The Law
}

\author{
Siti Barora Sinay \\ Fakultas Hukum Universitas Khairun, email: barorasiti@gmail.com
}

\begin{abstract}
Recognition and protection of indigenous and tribal peoples in the 1945 Constitution of the Republic of Indonesia formulated in Article 18B paragraph (2) in conjunction with Article 28I paragraph (3) reflects the recognition of conditional constitutionality which has not empirically reached the optimal point of protection where the certainty of recognition and protection of the rights of indigenous and tribal peoples depends on local government commitment. In realizing justice for indigenous peoples who tend to be discriminated against, it is necessary to commit to implementing "equality before the law" as a manifestation of the rule of law.
\end{abstract}

Keywords: Protection, Indigenous peoples, Rights, Equality before the law

\section{PENDAHULUAN}

Tujuan penyelenggaraan Negara sebagaimana dirumuskan pada alinea keempat pembukaan UUD Tahun 1945 adalah melindungi segenap bangsa Indonesia dan seluruh tumpah darah Indonesia, memajukan kesejahteraan umum, mencerdaskan kehidupan bangsa, ikut melaksanakan ketertiban dunia yang berdasarkan perdamaian abadi dan keadilan sosial. Hal ini bermakna bahwa segala warga Negara, warga bangsa termasuk tanah tumpah darah memperoleh jaminan perlindungan Negara yang disisi lain menempatkan kesejahteraan umum dan keadilan sosial sebagai muara penyelenggaraan pembangunan dalam bingkai kehidupan bermasyarakat dan berNegara yang tertib dan damai.

Masyarakat Adat ${ }^{1}$ sebagai subyek hukum warga Negara, juga diakui dan dihormati oleh Negara sebagaimana Pasal 18B ayat (2) UUD NRI Tahun 1945 yang menyatakan bahwa "Negara mengakui dan menghormati kesatuan-kesatuan masyarakat hukum adat serta hak tradisionalnya sepanjang masih hidup dan sesuai dengan perkembangan masyarakat dan prinsip Negara Kesatuan Republik Indonesia, yang diatur dalam Undang-Undang”. Hal ini mengandung 2 (dua) dimensi utama yakni (1) Dimensi Realitas yang memandang eksistensi entitas masyarakat adat beserta hak tradisionalnya yang tercermin dari pranata dan nilai adat yang selaras/tidak bertentangan dengan nilainilai keadaban; (2) Dimensi Ideal/Formal yang meletakan syarat subyektif formal

\footnotetext{
${ }^{1}$ Istilah resmi yang dipakai dalam pelbagai regulasi adalah Masyarakat Hukum Adat sebagai padanan dari Rechtgemeenschapt/adatrechtgemeenschap. Istilah masyarakat adat mengacu pada sejumlah kesepakatan internasional sebagai padanan dari indigeneous people.
} 
bahwa masyarakat adat sebagai subyek hukum yang memperoleh jaminan pengakuan dan penghormatan Negara sesuai dengan prinsip integratif NKRI yang diatur dalam Undang-Undang. Disisi lain, konsep pengakuan diatas mencerminkan pengakuan konstitusionalitas bersyarat (conditionally constitutionality).

Realitas empiris menunjukan bahwa masyarakat hukum adat yang telah ada dari generasi ke generasi semakin lebih terpinggirkan dan termarjinalkan karena berbagai alasan atas nama pembangunan maupun modernisasi. Kondisi ini menjadikan adanya disparitas masyarakat hukum adat pada aspek ekonomi, pendidikan dan sosial. Disisi lain, ketiadaan UU terkait Pengakuan dan Perlindungan Hak Masyarakat Hukum Adat menjadi titik lemah dalam mempertahankan eksistensi hukum adat, sekalipun syaratsyarat dapat dipenuhi oleh masyarakat hukum adat yang bersangkutan. Menurut Achmad Sodiki, hukum adat yang menjamin hak-hak adat berada pada posisi bertahan dan terus-menerus eksistensinya menghadapi hak-hak yang bersumber pada UndangUndang. Hal ini pulalah yang menjadi ancaman terhadap eksistensi pluralisme hukum Indonesia, karena UU mengusung kredo kebebasan dan persamaan dimuka hukum, padahal realitas sosial diskrepansi sosial, ekonomi, pendidikan, politik masih menyisakan jurang yang lebar antara satu daerah dengan daerah lainnya. ${ }^{2}$

Situasi masyarakat hukum adat yang termarjinalkan tersebut tentu saja mustahil tanpa sebab, disatu pihak, sifat hukum adat lebih mengutamakan unsur magis, kontan, kongkrit dan fleksibelitas yang dapat berfungsi efektif ketika nilai kejujuran, kebersamaan, dan gorong royong masih dilembagakan, sedangkan dilain pihak, Negara sebagai kuasa dan juga pengusaha lebih mendasarkan klaimnya atas hak-hak di dominasi oleh peraturan hukum, bukti yang formal dan tertulis. Oleh karena itu, terhadap perbedaan karakter masyarakat dan hukumnya, masyarakat hukum adat dan masyarakat secara umum tidak pernah ada kebijakan yang dapat mencari jalan keluar.

Dari teori tentang hukum dan keadilan, sebagaimana Gustav Radbruch dalam Bernard L. Tanya melukiskan keadaan diatas sebagai dimensi "sein" dengan "sollen" yang menyatakan bahwa gagasan hukum terarah pada rechtsidee keadilan sebagai satu cita yakni "yang sama diperlakukan sama, dan yang tidak sama diperlakukan tidak sama"3 maka bagi masyarakat hukum adat yang telah terdistorsi dan menjadikannya sebagai "second class, disadvantage group" harus diperlakukan tidak sama dalam konteks pemenuhan maupun perlindungan sesuai dengan kebutuhan masyarakat hukum adat dimaksud hingga memperoleh kedudukan yang setara. Hal ini menunjukan bahwa aspek keadilan menunjuk pada kesamaan hak didepan hukum "Equality before the law" bagi masyarakat hukum adat belumlah mencapai titik optimal perlindungan karena belum mengandung nilai kepastian dalam tafsir conditionally constitutionality norm.

\section{METODE PENELITIAN}

Tulisan ini menggunakan metode penelitian hukum normatif. Pendekatan dalam penelitian tesis ini sebagai bahan untuk mengawali dasar sudut pandang dan kerangka pikir penulis untuk melakukan analisis. Dalam penelitian ini penulis

\footnotetext{
${ }^{2}$ Achmad Sodiki, Hukum Progresif Untuk mewujudkan Keadilan Substantif dalam Bingkai NilaiNilai Pancasila (II), Makalah, 9 Maret 2012

3 Bernard L. Tanya dkk, 2013, Teori Hukum: Strategi Tertib Manusia Lintas Ruang dan Generasi, Genta Publishing, Yogyakarta, hlm. 116-117
} 
menggunakan pendekatan konseptual (conceptual approach) dan pendekatan perundang-undangan (statute approach). Pendekatan konseptual yaitu pendekatan yang menggunakan pandangan- pandangan dan doktrin-doktrin yang berkembang dalam ilmu hukum yang berkaitan dengan penelitian ini. ${ }^{4}$ Pendekatan perundang-undangan dimaksudkan bahwa peneliti menggunakan peraturan perundang sebagai dasar awal melakukan analisis. Hal ini harus dilakukan oleh peneliti karena titik objek penelitian ini tidak terlepas dari peraturan perundang-undangan khususnya peraturan perundang-undangan terkait perlindungan hukum masyarakat hukum adat.Bahan hukum terdiri dari bahan hukum primer,sekunder dan tersier. Analisis terhadap bahan-bahan hukum tersebut dilakukan dengan menggunakan metode pengkajian deskriptif analitis yaitu menelaah konsep, norma hukum dan sistem hukum yang berkaitan dengan perlindungan masyarakat hukum adat dalam konstitusi sebagai perwujudan asas equality before the law.

\section{ANALISIS}

Azas "equality before the law" sebagai tolok ukur keadilan dalam penerapannya terhadap masyarakat hukum adat dalam konteks Indonesia yang mewarisi kemajemukan budaya dan nilai masih menjadi diskursus hingga saat ini, disisi lain kondisi masyarakat adat yang semakin memprihatinkan baik sebagai individu maupun kelompok yang ditandai dengan derajat kesejahteraan yang rendah/miskin struktural, derajat pendidikan dan kesehatan yang rendah (buta huruf, angka kematian tinggi) hingga minimnya fasilitas pelayanan dasar mengingatkan kita akan rendahnya perhatian dan komitmen Pemerintah hingga Pemerintah Daerah.

\section{Equality is meaningless under unequal conditions}

Membicarakan eksistensi manusia dalam kehidupan bermasyarakat, berbangsa dan bernegara merupakan keprihatinan fundamental apalagi berkaitan dengan "Equality". Asas persamaan didepan hukum memberikan pemahaman adanya nilai dan pertimbangan yang sama bagi warga masyarakat. Asas ini diadopsi dalam sistem hukum Indonesia sebagai bagian dari instrumen HAM internasional (deklarasi, konvensi maupun akta parlemen).

Pasal 7 Universal Declaration of Human Rights 1948, merumuskan bahwa "All are equal before the law and are entitled without any discrimination to equal protection of the law". Hal ini mengandung makna rasionalitas anggapan bahwa manusia dilahirkan bebas (born free) ${ }^{5}$ sehingga memiliki kedudukan yang sama di hadapan hukum sehingga berhak untuk memperoleh perlindungan hukum yang sama tanpa diskriminasi. Rumusan norma ini direplikasi kedalam Pasal 26 International Covenant on Civil and Political Rights yang diratifikasi oleh Indonesia melalui UU Nomor 12 Tahun 2005 serta tersurat dalam UU Nomor 39 Tahun 1999 tentang Hak Asasi Manusia. French CJ, Crennan dan Kiefel JJ sebagaimana dikutip Anthony Hopkins merumuskan dasar-dasar persamaan dihadapan hukum, sebagai berikut:

\footnotetext{
${ }^{4}$ H. Zainuddin Ali, Metode Penelitian Hukum, Jakarta: Sinar Grafika, 2011, hlm 14

${ }^{5}$ Pasal 1 DUHAM menyatakan bahwa Semua orang dilahirkan merdeka dan mempunyai martabat dan hak-hak yang sama. Mereka dikaruniai akal dan hati nurani dan hendaknya bergaul satu sama lain dalam persaudaraan.
} 
"Equal justice embodies the norm expressed in the term equality before the law. It is an aspect of the rule of law. It was characterised by Kelsen as the principle of legality, or lawfulness, which is immanent in every legal order. It has been called the starting point of all other liberties. ",

Pengakuan persamaan dihadapan hukum ini bersifat imanen dalam setiap tatanan hukum sebagai titik awal dari semua kebebasan lainnya. Kesetaraan hukum berarti bahwa setiap orang tidak dapat didiskriminasi berdasarkan ras, warna kulit, jenis kelamin, bahasa, agama, pandangan politik atau lainnya, latar belakang kebangsaan atau sosial, kekayaan, status kelahiran atau lainnya, berkaitan dengan perlakuan terhadap mereka didepan hukum. Dalam praktik, hal ini meletakan kewajiban kepada negara untuk menjamin bahwa semua kelompok tunduk pada hukum yang sama serta memiliki hak yang sama. Hal ini disampaikan Sudikno Mertokusumo bahwa prinsip persamaan perlakuan di depan hukum menghendaki adanya keadilan dalam arti setiap orang adalah sama di depan hukum (equality before the law), setiap orang harus diperlakukan sama. ${ }^{7}$

Dalam konteks Negara hukum, Asas ini merupakan salah satu elemen penting sebagai bagian dari prinsip hak asasi manusia yang dimaknai sebagai seperangkat hak yang inheren pada diri manusia (rights that all human beings everywhere have or should have equally and in equal measure by virtue of their humanity) yang menurut A.V Dicey dalam Titon Slamet Kurnia, dalam suatu negara menuntut agar baik kedudukan warga Negara demikian pula pejabat pemerintah adalah sama dan tidak ada bedanya di muka hukum. ${ }^{8}$

Asas Persamaan dihadapan hukum adalah salah satu asas terpenting dalam hukum modern. Asas ini menjadi salah satu sendi doktrin Rule of Law yang juga menyebar pada negara-negara berkembang seperti Indonesia. Bagi Negara hukum Indonesia yang mengakui bahwa manusia tidak hanya dilahirkan bebas akan tetapi juga merupakan mahluk ciptaan Tuhan Yang Maha Esa berpandangan bahwa asas persamaan dihadapan hukum merupakan bagian dari hak asasi manusia yang bersifat fundamental untuk menjamin eksistensi kemanusiaan. Teori dan konsep equality before the law seperti yang dianut oleh Pasal 27 ayat (1) UUD NRI Tahun 1945 menjadi dasar perlindungan bagi warga Negara agar diperlakukan sama dihadapan hukum dan pemerintahan.

Asas equality before the law merupakan salah satu manifestasi dari Negara hukum (rechtstaat) sehingga harus adanya perlakuan sama bagi setiap orang di depan hukum (gelijkheid van ieder voor de wet). ${ }^{9}$ Dengan demikian, elemen yang melekat mengandung makna perlindungan sama di depan hukum (equal justice under the law) dan mendapatkan keadilan yang sama di depan hukum.

\footnotetext{
${ }^{6}$ Anthony Hopkins, 2015, Equality Before The Law: The Importance of Understanding the Experience of 'Others' in The Criminal Justice System, University of Canberra, hlm. 17 baca juga A.V Dicey, Introduction to the Study of the Law of the Constitution, (McMillan, 7th ed, 1908), hlm. 198

${ }^{7}$ Sudikno Mertokusumo, 2002, Mengenal Hukum Suatu Pengantar (cetakan keempat), Liberty, Yogyakarta, hlm. 36

${ }^{8}$ Titon Slamet Kurnia, Konsep Negara Berbasis Hak Sebagai Argumen Justifikasi Pengujian Konstitusionalitas Undang-Undang, Jurnal Konstitusi, Vol.9, No.3, September 2012, hlm. 564

${ }^{9}$ Lilik Mulyadi, 2007, Hukum Acara Pidana, Citra Aditya Bakti, Jakarta, hlm. 20
} 
Menurut H.L.A Hart dalam M. Ali Safa'at bahwa terdapat satu prinsip umum yang laten ketika keadilan diterapkan secara berbeda yaitu bahwa seorang individu diakui dalam penghargaan antara satu dengan lainnya atas suatu posisi relative tertentu berdasarkan kesamaan (equality) atau ketidaksamaan (unequality) dalam hal ini keadilan secara tradisional dipahami sebagai menjaga atau mengembalikan suatu keseimbangan atau proporsi dan persepsi ini sering diformulasikan sebagai "treath like cases alike" dan nantinya perlu ditambahkan "threat different cases differently". 10

Kriteria persamaan dan perbedaan seringkali dapat berfariasi sesuai dengan pandangan moral dasar seorang atau masyarakat tertentu. Karena itu, penilaian atas keadilan atau ketidakadilan hukum dapat bertemu tekanan balik yang diinspirasikan oleh moralitas yang berbeda. Jika sesuatu hukum yang memberikan penguasaan atas kepemilikan, maka persyaratan yang dibutuhkan untuk "like cases be threated alike" akan meliputi perhatian terhadap kebutuhan yang berbeda dari para pihak. ${ }^{11}$

Hukum akan adil hanya jika merefleksikan perbedaan manusia dan tindakannya dan memperlakukan kasus yang berbeda secara berbeda. Kadang-kadang "threat like cases alike" harus dikorbankan demi keselamatan umum atau kesejahteraan masyarakat. Ada batas penegakan hukum ketika suatu masyarakat dapat menerima suatu tindakan yang secara moral telah dilakukan. Sebaliknya, hukum, atas nama kesejahteraan umum masyarakat dapat memaksakan kompensasi dari seseorang yang merugikan orang lain, walaupun secara moral keadilan tidak perlu dilakukannya. Hal ini sering disebut sebagai keadilan sosial (social justice). ${ }^{12}$

Namun, Asas equality before the law dihadapan masyarakat yang tidak sama tidak ada artinya. Untuk bisa beroperasi secara adil, equality before the Law harus berada dalam situasi yang sama. Dalam negara hukum, pemerintah tidak boleh mengistimewakan orang atau kelompok orang tertentu, atau mendiskriminasikan orang atau kelompok orang tertentu. Oleh karena itu, penerapan asas persamaan dihadapan hukum haruslah melihat kedudukan subyek pemangku hak dan kewajiban apakah berada pada kedudukan dan situasi yang sama ataukah berbeda secara sistemik.

Kedudukan yang tidak setara antar subyek hukum akan menjadikan asas equality before of the law yang dimaksudkan untuk mewujudkan keadilan sebagaimana dimaksud oleh Hans Kelsen bahwa keadilan adalah suatu persoalan di wilayah "ought to be" bukan "is" sehingga bukan menjadi bagian dari kajian ilmu hukum positif karena keadilan adalah persoalan keharusan (ideal atau apa yang seharusnya) akan tetapi juga bersifat metayuridis. $^{13}$

Ide persamaan kedudukan yang ditegaskan penganut aliran hukum alam sebagai esensi keadilan, prinsip yang menyatakan bahwa segala sesuatu yang sama harus diperlakukan sama sebenarnya tidak mengemukakan apapun selain daripada prinsip identitas yang logis atau kontradiktif. Pemeriksaan perlakuan konseptual dari prinsip persamaan yang dilakukan oleh penganut teori hukum alam menemukan esensi keadilan didalamnya

\footnotetext{
${ }^{10}$ M. Ali Safa'at, 2016, Konsep Hukum H.L.A Hart, Konstitusi Press, Jakarta, hlm. 153

${ }^{11}$ Ibid, hlm. 157

12 Ibid, hlm. 159

${ }^{13}$ Hans Kelsen, 2008, Dasar-Dasar Hukum Normatif (Prinsip-Prinsip Teoritis untuk Mewujudkan Keadilan dalam Hukum dan Politik, Nusa Media, Jakarta, hlm. 358
} 
yang menunjukan bahwa mereka tidak pernah bisa menentukan apa atau siapa yang sama kedudukannya. ${ }^{14}$

Dengan demikian, perlindungan Negara sebagaimana Pasal 27 ayat (1) UUD 1945 meliputi baik bidang hukum privat maupun hukum publik, dengan demikian setiap warga negara mempunyai hak untuk mendapatkan perlindungan dengan mempergunakan kedua kelompok hukum tersebut dan jika ditilik selanjutnya tampak bahwa "hukum" yang dimaksud sebagai alat, sudah mencakup segi-segi keperdataan dan kepidanaan, serta cabang-cabang hukum publik lainnya, seperti hukum tata negara, hukum tata pemerintahan, hukum acara pidana/perdata dan sebagainya. perlindungan Negara dimaksud guna memastikan terciptanya kedudukan yang setara antar warga Negara sehingga dapat diterapkan asas persamaan dimuka hukum tersebut.

Asas persamaan kedudukan dihadapan hukum menurut UUD NRI Tahun 1945 adalah suatu mata rantai antara hak dan kewajiban yang harus berfungsi menurut kedudukannya masing-masing. Soenawar Soekowati sebagaimana dikutip Mien Rukmini menyatakan bahwa kesamaan dihadapan hukum berarti setiap warga Negara harus diperlakukan adil oleh Pemerintah, disisi lain warga Negara wajib mematuhi hukum dan peraturan yang berlaku. Meskipun warga Negara bebas menuntut haknya, namun kebebasan itu tidaklah seperti kebebasan demokrasi barat yang bila dibandingkan dengan filsafat barat yang menyatakan bahwa manusia dilahirkan bebas dan mempunyai persamaan hak dan seterusnya, terdapat perbedaan yang khas. ${ }^{15}$

\section{Cita Keadilan Dalam Perlindungan Masyarakat Hukum Adat}

Masyarakat adat adalah terjemahan dari kata Indigenous peoples ${ }^{16}$. Banyak orang membedakan pengertiannya dengan istilah masyarakat hukum adat yang merupakan terjemahan dari istilah Belanda Rechtsgemeenschap ${ }^{17}$. Penggunaan istilah masyarakat adat akan lebih luas maknanya bila dibandingkan dengan masyarakat hukum adat. Istilah masyarakat adat diyakini mempunyai dimensi makna yang luas dari sekedar aspek hukum, padahal dalam masyarakat adat sangat erat terkait dengan dimensi kultural, religi dan sebagainya, namun sebagai pendukung hak dan kewajiban, akan lebih tepat entitas masyarakat ditetapkan pada masyarakat hukum adat.

Cristina Ughi dalam The BSIS Journal of International Studies berpandangan bahwa:

"Indigenous communities can be "peoples" or "nations", having a "historical continuity with pre-invasion and pre-colonial societies that developed in their territories" and that "consider themselves distinct from other sectors of the societies now prevailing in those territories, or parts of them." They are also non dominant sectors of the society that seek to "preserve, develop and transmit to

\footnotetext{
${ }^{14}$ Hans Kelsen, 1973. General Theory of Law and State (alih bahasa Soemarno), Rimdi Press, Jakarta, hlm. 615

${ }^{15}$ Mien Rukmini, 2003, Perlindungan HAM melalui asas praduga tidak bersalah dan Asas Persamaan Kedudukan dalam Hukum pada Peradilan Pidana Indonesia, Alumni, Bandung, hlm. 24

${ }^{16}$ Istilah "Indigenous People" berarti kelompok orang/masyarakat yang hanya memiliki hak-hak individual, sedangkan "Indigenous Peoples" merujuk kepada kelompok orang/masyarakat yang memiliki hak-hak kolektif.

${ }^{17}$ Term "Rechtsgemeenschap" yang diterjemahkan menjadi masyarakat hukum agak bermasalah karena ada pula yang mengartikannya sebagai paguyuban hukum, atau juga persekutuan hukum (MM.Djojodinegoro).
} 
future generations their ancestral territories [and] their ethnic identity" as the basis of their continued existence as peoples, in accordance with their "own cultural patterns, social institutions and legal systems". ${ }^{18}$

Dalam Kongres Masyarakat Adat Nusantara I disepakati bahwa masyarakat adat adalah kelompok masyarakat yang memiliki asal usul leluhur (secara turun temurun) di wilayah geografis tertentu, serta memiliki sistem nilai, ideologi, ekonomi, politik, budaya, sosial dan wilayah sendiri.

Hazairin dalam Soekanto menyatakan bahwa masyarakat hukum adat adalah :

“... kesatuan-kesatuan kemasyarakatan yang mempunyai kelengkapankelengkapan untuk sanggup berdiri sendiri, yaitu mempunyai kesatuan hukum, kesatuan penguasa dan kesatuan lingkungan hidup berdasarkan hak bersama atas tanah dan air bagi semua anggotanya. Semua anggotanya sama dalam hak dan kewajibannya". ${ }^{19}$

Berdasarkan ketentuan Pasal 1 ayat (3) Peraturan Menteri Agraria Nomor 5 Tahun 1999 tentang Pedoman Penyelesaian Masalah Hak Ulayat Masyarakat Hukum Adat ditegaskan bahwa masyarakat hukum adat adalah sekelompok orang yang terikat oleh tatanan hukum adatnya sebagai warga bersama suatu persekutuan hukum karena kesamaan tempat tinggal ataupun atas dasar keturunan.

F.D. Hollemann dalam Otje Salman ${ }^{20}$ mengkonstruksikan 4 (empat) sifat umum dari masyarakat adat yaitu :

1) Magis Religius (Magisch-Religieus)

Sifat ini diartikan sebagai suatu pola pikir yang didasarkan pada religiusitas, yakni keyakinan masyarakat tentang adanya sesuatu yang bersifat sakral. Sebelum masyarakat hukum adat bersentuhan dengan sistem hukum agama, religiusitas ini diwujudkan dalam cara berpikir yang prelogika, animistis dan kepercayaan pada alam gaib yang menghuni suatu benda. Ada pula pendapat yang menyatakan bahwa sifat magis religius pada masyarakat animisme tidak jauh berbeda dengan masyarakat yang telah mengenal persentuhan sistem hukum agama dimana perasaan religius diwujudkan dalam bentuk kepercayaan terhadap Tuhan atas kepercayaan bahwa setiap perbuatan apapun bentuknya, akan selalu mendapatkan imbalan dan hukuman (reward and punishment) sesuai dengan derajat perbuatan.

2) Komunal (Commuun)

Masyarakat hukum adat memiliki asumsi bahwa setiap individu, anggota masyarakat merupakan bagian integral dari masyarakat secara keseluruhan. Diyakini pula bahwa setiap kepentingan individu sewajarnya disesuaikan dengan kepentingan-kepentingan masyarakat karena tidak ada individu yang terlepas dari masyarakatnya.

\footnotetext{
${ }^{18}$ Cristina Ughi, The "Right to Development" of Indigenous Peoples: A Critical Approach Through a Comparative Study of Cases Brought Before the Inter-American Court of Human Rights and the African Commission on Human and Peoples' RightsThe BSIS Journal of International Studies Vol 9 (2012), p. 3-4

${ }^{19}$ Soerdjono Soekanto dan Soleman B. Taneko, 1981. Hukum Adat Indonesia. Rajawali Press, Jakarta, hlm. 108

${ }^{20}$ H.R. Otje Salman Soemadiningrat,2015, Rekonseptualisasi Hukum Adat Kontemporer, Alumni, Bandung, hlm. 29-33
} 


\section{3) Konkret (Concret)}

Sifat ini diartikan sebagai corak yang serba jelas atau nyata, menunjukan bahwa setiap hubungan hukum yang terjadi dalam masyarakat tidak dilakukan secara diam-diam atau abstrak. Transaksi-transaksi yang terjadi merupakan perbuatan yang serba nyata.

4) Kontan (Kontante Handeling)

Sifat ini mengandung makna kesertamertaan, terutama dalam hal pemenuhan prestasi, dimana setiap pemenuhan prestasii selalu diiringi dengan kontra prestasi yang diberikan secara serta merta (seketika).

Ter Haar sebagaimana dikutip Bushar Muhammad membuat ciri-ciri masyarakat hukum adat (persekutuan hukum), sebagai berikut :

“...1) kesatuan manusia; 2) menetap disuatu daerah tertentu; 3) mempunyai penguasa-penguasa; 4) mempunyai kekayaan yang berwujud ataupun tidak berwujud, dimana para anggota kesatuan masing-masing menjalani kehidupan dalam masyarakat sebagai hal yang wajar menurut kodrat alam dan tidak ada seorangpun diantara para anggota tersebut mempunyai pikiran atau kecenderungan untuk membubarkan ikatan yang telah tumbuh atau meninggalkannya dalam arti melepaskan diri dari ikatan itu untuk selamalamanya.",21

Secara terminologis, "pengakuan" (erkenning) berarti proses, cara, perbuatan mengaku atau mengakui. Sedangkan kata "mengakui" berarti menyatakan "berhak". ${ }^{22}$ Husen Alting menyatakan bahwa pengakuan hak masyarakat hukum adat tidak hanya terbatas dalam bentuk pengakuan dalam hukum Negara, tetapi karena secara faktual masyarakat Indonesia bersifat majemuk (plural) maka pengakuan dapat diperoleh melalui hukum yang hidup dalam masyarakat yaitu hukum adat. ${ }^{23}$ Pengakuan hak atas tanah baik yang diatur dalam hukum Negara maupun hukum yang hidup dalam masyarakat, memiliki makna apabila ketentuan tersebut diikuti oleh tindakan perlindungan dari Negara.

Kata "perlindungan" tersusun dari kata dasar lindung yang berarti tempat berlindung atau hal (perbuatan). Perlindungan bermakna pemberian jaminan atas sesuatu sebagai konsekuensi dari sang pelindung. Menurut Satijipto Raharjo ${ }^{24}$, perlindungan hukum adalah memberikan pengayoman terhadap hak asasi manusia (HAM) yang dirugikan orang lain dan perlindungan itu di berikan kepada masyarakat agar dapat menikmati semua hak-hak yang diberikan oleh hukum. Hukum dapat difungsikan untuk mewujudkan perlindungan yang sifatnya tidak sekedar adaptif dan fleksibel, melainkan juga prediktif dan antisipatif. Hukum dibutuhkan untuk mereka yang lemah dan belum kuat secara sosial, ekonomi dan politik untuk memperoleh keadilan sosial.

${ }^{21}$ Bushar Muhammad, 1994. Asas-Asas Hukum Adat Suatu Pengantar, Pradnya Paramita, Jakarta, hlm. 22

${ }^{22}$ Kamus Besar Bahasa Indonesia, 2001, Departemen Pendidikan Nasional, Jakarta, hlm. 24

${ }^{23}$ Husen Alting, 2010, Dinamika Hukum Dalam Pengakuan dan Perlindungan Hak Masyarakat Hukum Adat Atas Tanah, LaksBang PRESSindo, Yogyakarta, hlm. 67

${ }^{24}$ Satjipto Raharjo, 2000, Ilmu Hukum, PT. Citra Aditya Bakti, Bandung, hlm. 55 
Berkaitan dengan perlindungan hukum yang dilakukan oleh Pemerintah, Philipus M. Hadjon membedakan menjadi 2 (dua) macam yaitu perlindungan hukum preventif dan perlindungan hukum represif. ${ }^{25}$

Perlindungan hukum preventif, rakyat diberi kesempatan untuk mengajukan keberatan (inspraak) atau pendapatnya sebelum suatu keputusan pemerintah diformulasikan dalam bentuk yang defenitif. Perlindungan hukum preventif bertujuan untuk mencegah terjadinya sengketa. Sedangkan perlindungan hukum represif merupakan upaya perlindungan yang dilakukan melalui Badan peradilan, baik peradilan umum maupun peradilan administrasi Negara. Perlindungan hukum represif bertujuan untuk menyelesaikan sengketa.

Penjabaran lebih lanjut mengenai hak masyarakat hukum adat diatur secara khusus dalam UUD NRI Tahun 1945 sebagai bagian dari Hak Asasi Manusia sebagaimana BAB XA, Pasal 28I ayat (3) yang menyatakan bahwa "Identitas budaya dan hak masyarakat tradisional dihormati selaras dengan perkembangan zaman dan peradaban". Dalam konteks UU Nomor 39 Tahun 1999, HAM merupakan seperangkat hak yang melekat pada hakikat dan keberadaan manusia sebagai mahluk Tuhan Yang Maha Esa dan merupakan anugrah-Nya yang wajib dihormati, dijunjung tinggi dan dilindungi oleh Negara, Hukum, Pemerintahan, dan setiap orang demi kehormatan serta perlindungan harkat dan martabat manusia. ${ }^{26}$ Dengan demikian, rumusan ketentuan dalam Pasal 28I ayat (3) UUD NRI Tahun 1945 tidak dapat dipandang sebagai norma mandiri akan tetapi secara ekstensif merupakan satu kesatuan pandangan mengenai Hak Masyarakat Adat untuk dapat memperoleh penghormatan, pemenuhan, perlindungan dan pengembangan dimensi hak asasinya.

Dalam perkembangannya, saat ini terdapat berbagai perundangan dibawah Konstitusi yang merumuskan ketentuan pengakuan dan dan kedudukan masyarakat adat beserta hak tradisionalnya diantaranya UU Nomor 5 Tahun 1960, UU Nomor 39 Tahun 1999, UU Nomor 41 Tahun 1999, UU Nomor 27 Tahun 2007, UU Nomor 32 Tahun 2009, dan UU Nomor 6 Tahun 2014.

UU No. 5 Tahun 1960 memuat ketentuan mengenai hak masyarakat adat khususnya berkaitan dengan ruang hidupnya yakni Hak Ulayat sebagaimana diatur dalam Pasal 3 yang menyatakan bahwa:

"Pelaksanaan Hak Ulayat dan hak-hak yang serupa itu dari masyarakatmasyarakat hukum adat, sepanjang menurut kenyataannya masih ada harus sedemikian rupa sehingga sesuai dengan kepentingan nasional dan Negara yang berdasarkan persatuan bangsa serta tidak bertentangan dengan undang-undang atau peraturan lain yang lebih tinggi."

\footnotetext{
${ }^{25}$ Philipus M. Hadjon, 1987, Perlindungan Hukum Bagi Rakyat Indonesia, Bina Ilmu, Surabaya, hlm. 29

${ }^{26}$ Pertimbangan filosofis UU No. 39 Tahun 1999 sebagaimana konsideran berpandangan bahwa manusia merupakan mahluk ciptaan Tuhan Yang Maha Esa yang mengemban tugas mengelola dan memelihara alam semesta dengan penuh ketaqwaan dan penuh tanggung jawab untuk kesejahteraan umat manusia, oleh pencipta-Nya dianugerahi hak asasi untuk menjamin keberadaan harkat dan martabat kemuliaan dirinya serta keharmonisan lingkungannya.
} 
Hal ini menunjukan bahwa pelaksanaan kewenangan masyarakat hukum adat atas wilayah tertentu yang merupakan lingkungan hidup para warganya untuk mengambil manfaat dari sumber daya alam bagi kelangsungan hidup dan kehidupannya dirumuskan sebagai hak ulayat bersyarat. Disisi lain, regulasi ini juga menetapkan kedudukan tanah hak ulayat sebagai entitas tersendiri yang berdampingan dengan tanah Negara dan tanah hak yang diturunkan dari konsep hak bangsa berlandaskan pada asas komunalistik religius.

Masyarakat Adat beserta hak tradisionalnya dalam perspektif UU Nomor 39 Tahun 1999 secara tegas dirumuskan dalam Pasal 6 yang menyatakan bahwa identitas budaya masyarakat hukum adat, termasuk hak atas tanah ulayat dilindungi, selaras dengan perkembangan zaman serta mengharuskan pemerintah untuk memperhatikan dan melindungi segala perbedaan dan kebutuhan dalam masyarakat hukum adat. Dengan demikian, dalam kerangka penegakan HAM Negara mengemban kewajiban serta dapat dipertanggungjawabkan manakala terjadi pelanggaran HAM.

Pengaturan Hak Masyarakat Adat dalam UU Nomor 41 Tahun 1999 terkait Ruang Hidup masyarakat adat baru mendapat titik terang pasca putusan MK Nomor 35/PUU$\mathrm{X} / 2012$ yang mengandung dua isu konstitusional yakni Hutan Adat dan pengakuan bersyarat terhadap keberadaan masyarakat adat. Hal ini ditegaskan dalam Pasal 4 ayat (3) bahwa penguasaan hutan oleh Negara tetap memperhatikan hak masyarakat hukum adat, sepanjang dalam kenyataannya masih ada dan diakui keberadaannya serta tidak bertentangan dengan kepentingan nasional. Terkait Hutan Adat, perubahan Pasal 1 angka $6^{27}$ UU Kehutanan ini menempatkan posisi hutan adat (ada yang disebut hutan marga, hutan pertuanan atau sebutan lainnya) berada dalam cakupan hak ulayat karena berada dalam satu kesatuan wilayah (ketunggalan wilayah) masyarakat hukum adat, yang peragaannya didasarkan atas leluri (traditio) yang hidup dalam suasana rakyat (in de volksfeer) dan mempunyai suatu badan perurusan pusat yang berwibawa dalam seluruh lingkungan wilayahnya. ${ }^{28}$ Secara khusus BAB IX merumuskan pengaturan masyarakat hukum adat diantaranya hak masyarakat hukum adat menurut Pasal 67 ayat (1) meliputi:

1) melakukan pemungutan hasil hutan untuk pemenuhan kebutuhan hidup sehari-hari masyarakat adat yang bersangkutan;

2) melakukan kegiatan pengelolaan hutan berdasarkan hukum adat yang berlaku dan tidak bertentangan dengan undang-undang; dan

3) mendapatkan pemberdayaan dalam rangka meningkatkan kesejahteraannya.

Bagi masyarakat adat, ruang hidup tidak hanya berupa tanah/hutan semata akan tetapi juga air, pantai dan laut. UU Nomor 27 Tahun 2009 jo UU Nomor 1 Tahun 2014 mengakomodasi kepentingan ini melalui kewajiban memperhatikan kepentingan masyarakat adat dalam pengelolaan pesisir sekaligus menjadi salah satu subyek pemberian hak pengusahaan perairan pesisir dengan mengintegrasikan wilayah masyarakat masyarakat hukum adat kedalam RZWP3K. ${ }^{29}$ Pasal $61 \mathrm{UU}$ ini secara tegas merumuskan bahwa Pemerintah mengakui, menghormati, dan melindungi hak-hak

${ }^{27}$ Pasal 1 angka 6 pasca Putusan MK No. 35/PUU-X/2012 berbunyi Hutan Adat adalah hutan Negara yang berada dalam wilayah masyarakat hukum adat.

${ }^{28}$ Putusan MK No. 35/PUU-X/2012, hlm. 172-3

${ }^{29}$ UU No. 1 Tahun 2014, Pasal I angka 17 mengubah rumusan Pasal 60 UU No. 27 Tahun 2007 
masyarakat adat dan kearifan lokal atas wilayah pesisir dan pulau-pulau kecil yang telah dimanfaatkan secara turun-temurun serta dijadikan acuan dalam pengelolaan wilayah pesisir dan pulau-pulau kecil berkelanjutan

Keberlanjutan fungsi lingkungan hidup yang merupakan bagian dari local wisdom, namun dalam UU Nomor 32 Tahun 2009 hanya merumuskan tugas dan wewenang Pemerintah/Pemerintah Daerah yakni menetapkan kebijakan mengenai tata cara pengakuan keberadaan masyarakat hukum adat, kearifan lokal, dan hak masyarakat hukum adat yang terkait dengan perlindungan dan pengelolaan lingkungan hidup. ${ }^{30}$

Pengaturan tata pemerintahan dalam UU Nomor 6 Tahun 2014 menegaskan status Desa Adat dengan salah satu kewenangan yakni kewenangan berdasarkan hak asal usul. Ketentuan khusus Desa Adat ini diatur dalam BABXIII antara lain syarat penetapan desa adat, kewenangan desa adat, pemerintahan desa adat, dan peraturan desa adat. Pasal 97 merumuskan bahwa syarat Penetapan Desa Adat berdasarkan kriteria wilayah (territorial) sebagai kriteria wajib serta syarat alternatif yakni kesatuan masyarakat hukum adat beserta hak tradisionalnya secara nyata masih hidup, sesuai dengan perkembangan masyarakat dan prinsip NKRI. Kewenangan berdasarkan hak asal usul, meliputi:

a. pengaturan dan pelaksanaan pemerintahan berdasarkan susunan asli;

b. pengaturan dan pengurusan ulayat atau wilayah adat;

c. pelestarian nilai sosial budaya Desa Adat;

d. penyelesaian sengketa adat berdasarkan hukum adat yang berlaku di Desa Adat dalam wilayah yang selaras dengan prinsip hak asasi manusia dengan mengutamakan penyelesaian secara musyawarah;

e. penyelenggaraan sidang perdamaian peradilan Desa Adat sesuai dengan ketentuan peraturan perundang-undangan;

f. pemeliharaan ketenteraman dan ketertiban masyarakat Desa Adat berdasarkan hukum adat yang berlaku di Desa Adat; dan

g. pengembangan kehidupan hukum adat sesuai dengan kondisi sosial budaya masyarakat Desa Adat.

Rumusan norma hukum terkait masyarakat adat/masyarakat hukum adat diatas menunjukan bahwa klaim kedaulatan masyarakat hukum adat tidak diterapkan, meskipun instrumen hukum nasional dan internasional telah mendukungnya. Hal ini terlihat dari adanya rumusan norma hukum bersyarat dalam batasan-batasan hak menguasai Negara. Disisi lain, secara eksternal terkait gerakan kemandirian masyarakat itu sendiri, yakni terkait dengan kelangsungan pengawasan tanah agrarian terhambat pengakuan pemerintah terhadap prinsip-prinsip adat dengan penolakan terhadap sebagian khusus klaim adat. Oleh karena itu, dalam rangka pencapaian cita keadilan terkait perlindungan masyarakat hukum adat perlu dilakukan langkah-langkah strategis dalam rangka pengakuan dan perlindungan serta menempatkan masyarakat hukum adat dalam posisi sederajat dengan warga Negara lainnya baik secara invidual maupun kolektif.

Hans Kelsen dalam bukunya General Theory of Law and State menguraikan pengakuan dalam kaitan dengan keberadaan suatu Negara, sebagai berikut:

\footnotetext{
${ }^{30}$ UU No. 32 Tahun 2009 Pasal 63
} 
"terdapat dua tindakan dalam suatu pengakuan yakni tindakan politik dan tindakan hukum. Tindakan politik mengakui suatu Negara (keberadaan masyarakat hukum adat-Penulis) berarti Negara mengakui berkehendak untuk mengadakan hubungan-hubungan politik dan hubungan-hubungan lain dengan masyarakat yang diakuinya. Sedangkan tindakan hukum adalah prosedur yang dikemukakan diatas yang ditetapkan oleh hukum internasional (hukum nasionalpenulis) untuk menetapkan fakta Negara (masyarakat hukum adat-penulis) dalam suatu kasus konkrit."

Menurut Achmad Sodiki, perlindungan terhadap pengakuan hukum adat dapat dilakukan dengan beberapa pilihan, sebagai berikut:

a. Jika hukum adat dianggap sejajar dengan undang-undang, hal ini berarti kembali pada posisi sebelum merdeka yakni berlakunya hukum adat yang diperuntukan bagi golongan bumi putera sehingga terdapat kesamaan derajat dengan KUHPerdata yang diperuntukan bagi golongan Eropa dan Timur Asing, Tionghoa. Dengan demikian, hukum tanah mengikuti hukum adat dan hukum perdata barat.

b. Jika pengakuan hukum adat dibawah ketentuan hukum undang-undang, maka keberadaan hukum adat bergantung sekali dengan belas kasihan undang-undang.

c. Jika hukum adat tidak sejajar dengan hukum undang-undang, maka keadaan akan terjadi sebagaimana terjadi dewasa ini akibat implikasi langsung pada penerapan hak menguasai Negara.

d. Jika hukum adat berada diatas hukum Negara, maka hal ini dapat terjadi jika hukum adat diambil bagian yang merupakan moralitas hukum. Bagaimanapun juga hukum adat yang hidup merupakan cerminan moralitas hukum masyarakat Indonesia. $^{32}$

Prinsip mengakui dan menghormati kesatuan masyarakat hukum adat beserta hak tradisionalnya telah ditegaskan dalam Pasal 18B ayat (2) UUD NRI Tahun 1945 yang oleh Bagir Manan sebagaimana dikutip Husen Alting, bahwa:

"kesatuan masyarakat hukum adat berhak atas segala perlakukan dan diberi kesempatan berkembang sebagai subsistem Negara Kesatuan RI yang maju, sejahtera dan modern. Hak-hak tradisional yang ada diakui dan dijunjung tinggi meliputi hak ulayat, hak-hak memperoleh manfaat atau kenikmatan dari tanah dan air atau hasil hutan, dll. Pengakuan dan penghormatan tersebut bukan berarti menjadi hak yang tidak dapat disentuh atau diatur, namun pengaturan tersebut harus benar-benar untuk sebesar-besarnya kemakmuran bersama tanpa merugikan kepentingan masyarakat yang mempunyai hubungan dengan hak tradisional tersebut." 33

Birgitte Feiring mengatakan bahwa hak tradisional indigenous people sebagaimana ICCPR, ICESCR, UNDRIP dan ILO Convention No. 169, sebagai berikut:

${ }^{31}$ Hans Kelsen, 1973. General ... opcit, hlm 222. Baca juga Husen Alting, Penguasaan Tanah Masyarakat Hukum Adat (Kajian terhadap Masyarakat Hukum Adat Ternate), Jurnal Dinamika Hukum, Vol 11 Nomor 1 Januari 2011, hlm. 89-90

${ }^{32}$ Achmad Sodiki, Politik Hukum Agraria; Unifikasi atau Pluralisme Hukum, 1999, Jurnal Arema Hukum Nomor 8, hlm. 101

${ }^{33}$ Husen Alting, opcit, hlm. 37-38 
"Indigenous peoples land rights comprise both individual and collective aspects. Whereas most indigenous peoples have customary ways of recognising land and resource rights of individual members or households, the collective aspects of their rights to lands, territories, and resources are intrinsically linked to their collective rights to self-determination, nondiscrimination, cultural integrity, and development as distinct peoples. Indigenous peoples have rights to the lands, territories, and resources that they have traditionally occupied, owned, or used, meaning that it is "the traditional occupation and use which is the basis for establishing indigenous peoples' land rights, and not the eventual official recognition or registration of that ownership". ${ }^{34}$

Cita keadilan yang berwujud kebahagiaan melalui asas equality before the law diwujudkan melalui perlindungan hukum kepada masyarakat hukum adat. Perlindungan hukum adalah perlindungan akan harkat dan martabat, serta pengakuan terhadap hakhak asasi manusia yang dimiliki oleh subyek hukum berdasarkan ketentuan hukum dari kesewenangan atau sebagai kumpulan peraturan atau kaidah yang akan dapat melindungi suatu hal dari hal lainnya. Hal ini akan memperkuat kesetaraan posisi masyarakat hukum adat dengan warga Negara lainnya.

Valery Surovtsev dalam Journale of Procedia - Social and Behavioral Sciences, menyatakan bahwa:

"Justice as fairness is an exercise in "ideal theory." It aims to develop principles for the evaluation of a well-ordered society. First, in any actual society there will be some people who have an inadequate or mistaken sense of justice. Second, justice as fairness has little to say about the transition from existing social injustices to a more just basic structure". ${ }^{35}$

Perlindungan masyarakat hukum adat setelah adanya UU Nomor 6 Tahun 2014 tidak bisa dikaji hanya dengan menggunakan instrumen hukum ini, akan tetapi berkaitan dengan hak asal-usul dan/atau hak tradisional pada ruang hidup masyarakat hukum adat secara komprehensif mengkaji perundang-undangan sektoral yang menerjemahkan filosofi perumusan norma dasar Pasal 33 ayat (3) UUD NRI Tahun 1945 yang meletakkan kekuasaan Negara sebagai organisasi kekuasaan seluruh rakyat. Rumusan ini memperlihatkan bagaimana Negara berpikir (denken), berkehendak (willen) serta berbuat dan bertindak (handeling) dengan dalil kewenangan atas bumi, air, kekayaan alam yang terkandung didalamnya termasuk ruang angkasa. Lebih lanjut dijabarkan dalam UU Nomor 5 Tahun 1960, UU Nomor 41 Tahun 1999 masih dengan lingkup pengaturan yang menempatkan Negara pada posisi tertinggi penguasaan sumber-sumber agraria (dalam arti luas), sedangkan entitas lainnya termasuk masyarakat hukum adat terikat pada pengakuan bersyarat.

Klausula persyaratan ini menunjukan bahwa terjadi penundukan hukum adat terhadap hukum Negara yang oleh Jhon Griffiths sebagai pluralisme hukum yang lemah (weak law pluralism) karena hukum adat hanya dapat berlaku jika keberadaannya diakui oleh hukum Negara. Pengakuan terhadap masyarakat hukum adat beserta hak tradisionalnya juga berimplikasi pada adanya kepastian hukum termasuk pengakuan Negara terhadap

34 Birgitte Feiring, 2013. Indigenous peoples' rights to lands, territories, and resources, International Land Coalition, hlm. 17-18

${ }^{35}$ Valery Surovtsev, Outlooks of J. Rawls's theory of justice, Procedia - Social and Behavioral Sciences 166 (2015) 176 - 181, p. 177 
lembaga peradilan adat yang menangani permasalahan masyarakat hukum adat menurut "hukum adat yang diakui". ${ }^{36}$ Disisi lain, penataan desa menjadi desa adat diarahkan pada kemandirian Desa untuk mewujudkan kesejahteraan masyarakat sebagaimana konsep welfare state. Sejalan dengan terminologi hak menguasai Negara di dalam rumusan norma hukum Pasal 33 UUD NRI 1945 menurut Mohammad Hatta sebagaimana dikutip Yance Arizona sebagai dikuasai oleh negara yang tidak berarti bahwa negara sendiri menjadi pengusaha, usahawan atau ordernemer. Lebih tepat dikatakan bahwa kekuasaan Negara terdapat pada membuat peraturan guna kelancaran jalan ekonomi, peraturan yang melarang pula penghisapan orang yang lemah oleh orang yang bermodal. ${ }^{37}$

Hukum Adat sebagai hukum yang hidup (living law) dikonsepsikan sebagai suatu sistem hukum yang terbentuk dan berasal dari pengalaman empiris masyarakat masa lalu, yang dianggap adil atau patut dan telah mendapatkan legitimasi dari penguasa adat sehingga mengikat atau wajib dipatuhi (bersifat normatif). Dengan demikian, Negara harus mengabdikan diri untuk mengakomodasi hak masyarakat hukum adat sebagaimana pandangan Jawahir Thontowi, bahwa:

"untuk kepentingan ke depan, pengakuan dan penghormatan terhadap otonomi komunitas (desa) dimaksudkan untuk menjawab masa depan terutama merespon proses globalisasi, yang ditandai oleh proses liberalisasi (informasi, ekonomi, teknologi, budaya, dan lain-lain) dan munculnya pemain-pemain ekonomi dalam skala global. Dampak globalisasi dan eksploitasi oleh kapitalis global tidak mungkin dihadapi oleh lokalitas, meskipun dengan otonomi yang memadai. Tantangan ini memerlukan institusi yang lebih kuat (dalam hal ini negara) untuk menghadapinya., 38

Oleh karena itu, berangkat dari pandangan Hans Kelsen tentang bentuk ideal keadilan berkenaan dengan ide persamaan kedudukan (equality) haruslah didasari pemikiran bahwa segala sesuatu yang sama berhak mendapatkan yang sama, suum cuique sebagai bentuk tatanan, kesatuan dalam sistem yang tidak pernah ditemukan kesetaraan kedudukan akibat perbedaan yang manusiawi, maka diperlukan affirmative untuk mendorong kesetaraan kedudukan para pihak sebagaimana pandangan Kelsen, yaitu:

“prinsip persamaan kedudukan sebagai sebuah prinsip keadilan hanyalah berarti bahwa jika A harus diperlakukan dalam suatu cara tertentu dan B setara dengan A, maka kemudian B harus diperlakukan dalam cara yang sama. Jika tidak demikian, akan ada kontradiksi logis dimana prinsip persamaan kedudukan akan dirusak dan gagasan tentang kesatuan sistem-sistem akan runtuh., 39

Dengan demikian, bagi masyarakat hukum adat pelaksanaan pengakuan Negara terhadap masyarakat hukum adalah dimaksudkan untuk mencapai kedaulatan masyarakat hukum adat. Pengakuan ini merupakan komitmen politik dan dilegalisasi oleh hukum. Namun, jika dibandingkan dengan sejarah politik pengakuan sebagaimana

\footnotetext{
${ }^{36}$ Jhon Griffiths, 2005, Memahami Pluralisme Hukum, Sebuah Deskripsi Konseptual dalam Pluralisme Hukum sebuah Pendekatan Interdisiplin, HUMA, Jakarta, hlm. 77-78

37 Yance Arizona, Perkembangan Konstitusionalitas Penguasaan Negara atas Sumber Daya Alam dalam Putusan Mahkamah Konstitusi, Jurnal Konstitusi, Volume 8, Nomor 3, Juni 2011, hlm. 260

${ }^{38}$ Jawahir Thontowi, Perlindungan dan Pengakuan Masyarakat Adat dan Tantangannya dalam Hukum Indonesia, Jurnal Hukum Ius Quia Iustum Nomor 1 Vol. 20 Januari 2013, hlm. 21 - 36

${ }^{39}$ Hans Kelsen, 1973. General ..., Opcit, hlm 615-616.
} 
rumusan awal Pasal 18 UUD Tahun 1945 dimana dalam penjelasan Pasal menyatakan bahwa :

"Dalam territori Negara Indonesia terdapat lebih kurang 250 zelfbesturende landchappen dan volksgemeenschappen, seperti desa di Jawa dan Bali, negeri di Minangkabau, dusun dan marga di Palembang dan sebagainya. Daerah-daerah itu mempunyai susunan asli, dan oleh karenanya dapat dianggap sebagai daerah yang bersifat istimewa. Negara Republik Indonesia menghormati kedudukan daerahdaerah istimewa tersebut dan segala peraturan negara yang mengenai daerahdaerah itu akan mengingati hak-hak asal-usul daerah tersebut."

Penjelasan Pasal diatas menunjukan bahwa baik zelfbesturende landchappen (daerah swaparaja) maupun volksgemeenschappen (daerah masyarakat hukum adat) merupakan daerah yang bersifat istimewa yang keberadaan dan eksistensinya diakui secara otomatis dalam UUD 1945 sebelum perubahan, tanpa adanya persyaratan konstitusional tertentu. Namun, tidak memberikan penegasan terkait bentuk pengakuan dan perlindungan terhadap masyarakat hukum adat. Politik hukum terkait perlindungan masyarakat hukum adat mengalami kemunduran sistematis atas nama pembangunan yang ditandai dengan peminggiran hak masyarakat hukum adat dan minoritas sehingga menempatkan masyarakat hukum adat dalam posisi termarjinal hingga saat ini. Kedudukan hukum adat juga menjadi subordinasi dengan hukum Negara sehingga keberadaan hukum adat bergantung sekali dengan belas kasihan undang-undang.

Oleh karena itu, filosofi perlindungan masyarakat hukum adat selaras dengan pandangan Satijipto Raharjo ${ }^{40}$ dimaksudkan untuk memberikan pengayoman terhadap hak asasi manusia (HAM) yang dirugikan orang lain dan perlindungan itu di berikan kepada masyarakat agar dapat menikmati semua hak-hak yang diberikan oleh hukum dalam rangka memperoleh keadilan sosial.

Langkah-langkah strategis pelaksanaan perlindungan kepada masyarakat hukum adat guna mencapai keadilan sosial adalah mendorong disahkannya RUU Pengakuan dan Perlindungan Masyarakat Hukum Adat, penetapan pengakuan masyarakat hukum adat beserta hak ulayat dan ruang hidup yang didasari oleh self assessment/internal assessment masyarakat hukum adat sendiri yang ditetapkan oleh Pemerintah/Pemerintah Daerah, penerapan affirmative dalam menumbuhkembangkan kapasitas dan keterlibatan masyarakat hukum adat terkait pelaksanaan hak asal usul berdasarkan UU Nomor 6 Tahun 2014 serta petunjuk teknis dalam Peraturan Menteri Desa, pembangunan Daerah Tertinggal dan Transmigrasi Nomor 1 Tahun 2015 tentang Pedoman Kewenangan Berdasarkan Hak Asal Usul dan Kewenangan Lokal Berskala Desa.

\section{SIMPULAN}

Negara secara konstitusional telah memberikan pengakuan akan entitas masyarakat hukum adat yang merupakan bagian dari warga negara yang semestinya secara seimbang juga memberi penghormatan akan identitas masyarakat hukum adat sebagai subyek hukum yakni hak yang sama dapat hidup sejahtera sebagaimana tujuan pembangunan nasional.

\footnotetext{
${ }^{40}$ Satjipto Raharjo, 2000, Ilmu Hukum, PT. Citra Aditya Bakti, Bandung, hlm. 55
} 
Secara filosofi, cita nilai keadilan bersendikan pada Asas equality before the law yang tidak dapat diterapkan dalam kedudukan masyarakat hukum adat yang tidak seimbang karena asas persamaan dihadapan hukum tidak akan bermakna dalam situasi yang tidak sama/sederajat.

Pengakuan masyarakat hukum adat lebih bersifat deklaratif sehingga pengakuan pemerintah idealnya memberikan pengaruh kepercayaan diri dalam mengelola sumber daya alam yang ada sehingga dapat tercapai cita-cita welfare state. Untuk mencapai keadilan sosial masyarakat hukum adat harus didorong untuk mencapai kesederajatan melalui pengesahan RUU pengakuan dan perlindungan masyarakat hukum adat, pengakuan dan penetapan masyarakat hukum adat beserta lebensraumnya, serta penguatan kapasitas dan keterlibatan masyarakat hukum adat dalam pelaksanaan pembangunan.

\section{Daftar Pustaka}

Anthony Hopkins, 2015, Equality Before The Law: The Importance of Understanding the Experience of 'Others' in The Criminal Justice System, University of Canberra

Achmad Sodiki, Hukum Progresif Untuk mewujudkan Keadilan Substantif dalam Bingkai Nilai-Nilai Pancasila (II), Makalah, 9 Maret 2012

A.V Dicey, Introduction to the Study of the Law of the Constitution, (McMillan, 7th ed, 1908).

Bernard L. Tanya dkk, 2013, Teori Hukum: Strategi Tertib Manusia Lintas Ruang dan Generasi, Genta Publishing, Yogyakarta

Bushar Muhammad, 1994. Asas-Asas Hukum Adat Suatu Pengantar, Pradnya Paramita, Jakarta

Birgitte Feiring, 2013. Indigenous peoples' rights to lands, territories, and resources, International Land Coalition

Hans Kelsen, 2008, Dasar-Dasar Hukum Normatif (Prinsip-Prinsip Teoritis untuk Mewujudkan Keadilan dalam Hukum dan Politik, Nusa Media, Jakarta

H. Zainuddin Ali, Metode Penelitian Hukum, Jakarta: Sinar Grafika, 2011 1973. General Theory of Law and State (alih bahasa Soemarno), Rimdi Press, Jakarta

H.R. Otje Salman Soemadiningrat,2015, Rekonseptualisasi Hukum Adat Kontemporer, Alumni, Bandung

Husen Alting, 2010, Dinamika Hukum Dalam Pengakuan dan Perlindungan Hak Masyarakat Hukum Adat Atas Tanah, LaksBang PRESSindo, Yogyakarta

Jhon Griffiths, 2005, Memahami Pluralisme Hukum, Sebuah Deskripsi Konseptual dalam Pluralisme Hukum sebuah Pendekatan Interdisiplin, HUMA, Jakarta

Kamus Besar Bahasa Indonesia, 2001, Departemen Pendidikan Nasional, Jakarta

Lilik Mulyadi, 2007, Hukum Acara Pidana, Citra Aditya Bakti, Jakarta

M. Ali Safa'at, 2016, Konsep Hukum H.L.A Hart, Konstitusi Press, Jakarta 
Mien Rukmini, 2003, Perlindungan HAM melalui asas praduga tidak bersalah dan Asas Persamaan Kedudukan dalam Hukum pada Peradilan Pidana Indonesia, Alumni, Bandung

Philipus M. Hadjon, 1987, Perlindungan Hukum Bagi Rakyat Indonesia, Bina Ilmu, Surabaya

Satjipto Raharjo, 2000, Ilmu Hukum, PT. Citra Aditya Bakti, Bandung

Soerdjono Soekanto dan Soleman B. Taneko, 1981. Hukum Adat Indonesia. Rajawali Press, Jakarta

Sudikno Mertokusumo, 2002, Mengenal Hukum Suatu Pengantar (cetakan keempat), Liberty, Yogyakarta

Achmad Sodiki, Politik Hukum Agraria; Unifikasi atau Pluralisme Hukum, 1999, Jurnal Arema Hukum Nomor 8

Cristina Ughi, The "Right to Development" of Indigenous Peoples: A Critical Approach Through a Comparative Study of Cases Brought Before the Inter-American Court of Human Rights and the African Commission on Human and Peoples' Rights, The BSIS Journal of International Studies Vol 9, 2012

Jawahir Thontowi, Perlindungan dan Pengakuan Masyarakat Adat dan Tantangannya dalam Hukum Indonesia, Jurnal Hukum Ius Quia Iustum Nomor 1 Vol. 20 Januari 2013

Titon Slamet Kurnia, Konsep Negara Berbasis Hak Sebagai Argumen Justifikasi Pengujian Konstitusionalitas Undang-Undang, Jurnal Konstitusi, Vol.9, No.3, September 2012

Valery Surovtsev, Outlooks of J. Rawls's theory of justice, Procedia - Social and Behavioral Sciences 166, 2015

Yance Arizona, Perkembangan Konstitusionalitas Penguasaan Negara atas Sumber Daya Alam dalam Putusan Mahkamah Konstitusi, Jurnal Konstitusi, Volume 8, Nomor 3, Juni 2011 